\author{
Elwira Żmudzka \\ University of Warsaw - Faculty of Geography and Regional Studies - Department of Climatology \\ 00-927 Warsaw, Krakowskie Przedmieście 30, \\ e-mail: elwiraz@uw.edu.pl
}

\title{
THE INFLUENCE OF CLOUDINESS ON AIR TEMPERATURE AND PRECIPITATION ON THE TERRITORY OF POLAND (1951-2000)
}

\begin{abstract}
Analysis of time series was performed of cloudiness, air temperature and precipitation for the years 1951-2000, the data used representing lowland Poland. The properties of the temporal course of these elements of climate and the interrelations between their variability in time have been determined. The strength of dependence of precipitation and temperature upon the magnitude of cloudiness in the annual cycle has been assessed with the linear correlation coefficient. The essential climate-forming role of cloudiness has been confirmed. The magnitude of cloudiness over Poland explains up to $70 \%$ of variability of temperature and precipitation. These interrelations are the strongest in the warmer half of the year. Atmospheric circulation and cloudiness explain up to $85 \%$ of variability of the climate elements studied.
\end{abstract}

Key words: cloudiness; temperature; rainfall; atmospheric circulation; Poland; variability; relationships

\section{INTRODUCTION}

One of the most important elements of weather and climate, which is, simultaneously, attributed high climate-forming significance, is constituted by cloudiness. It was demonstrated (Svensmark \& FriisChristensen 1997) that the increase of cloudiness, being an important factor modifying the radiation exchange in the atmosphere, by just $2 \%$, may contribute to the reduction of the currently observed greenhouse effect, and thus limit the increase of air temperature. The magnitude 
of cloudiness and the genus of cloud influence, as well, another leading element of climate - the quantity and the form of precipitation.

An important instrument, used in explanation of changes and variability of climate, is constituted by the general circulation models, in which, additionally, information on interrelations between individual elements of weather (climate) is accounted for. Assessment of the relations between cloudiness and atmospheric circulation (see, e.g., Barry et al. 1987; Cess et al. 1996) and of the joint impact of cloudiness and other elements of climate (see, e.g., Wetherald \& Manabe 1980; Norris 2004) still makes an interesting research problem.

The primary purpose of the study here reported was to determine the relations between the temporal changes in the magnitude of cloudiness and air temperature, as well as precipitation, over the area of lowland Poland, representing the territory of Central Europe. Likewise, an assessment has been made of the contribution of the atmospheric circulation and the magnitude of cloudiness to the shaping of these elements of climate.

\section{THE STUDY MATERIAL AND THE METHODS}

The influence exerted by cloudiness on air temperature and precipitation was determined by considering the time series of these elements of climate, averaged over the area of lowland Poland. They were obtained on the basis of homogeneous series of average monthly values of these elements from the years 1951-2000, measured at, respectively, 48, 45 and 50 weather stations of the Institute of Meteorology and Water Management, situated at less than $300 \mathrm{~m}$ a.s.l. The area averaged data are often used in general characterisation of climate and also in the studies of the rate of its changes (Fortuniak et al. 2001; Żmudzka 2006, 2007).

The strength of dependence of precipitation and temperature upon the magnitude of cloudiness over Poland was assessed with the use of the linear correlation coefficient. Besides, comparison was performed of their long-term tendencies (linear trend directional coefficients), of fluctuations (determined on the basis of the courses of cumulative deviations from the long-term average for 1951-2000), of the periodical changes (identified with the method of the "regression sinusoids", Boryczka, 1998, and with application of the wavelet analysis, Torrence 
\& Compo 1998), as well as the calendars (based on percentile intervals). Attention was paid to the specific features of their annual courses.

In order to determine the role that the cloudiness plays, along with the atmospheric circulation, in the shaping of air temperature and precipitation, the coefficients were calculated of correlation and multiple regression. Atmospheric circulation was described with the vector of geostrophic wind over central Europe (Kożuchowski \& Żmudzka 2002; Degirmendžić et al. 2004).

\section{THE RESULTS}

During the entire year the magnitude of cloudiness significantly influences the amount of precipitation (Table 1). This positive relation is the strongest in summer and autumn, and the weakest in winter. The dependence of air temperature upon the magnitude of cloudiness is somewhat weaker. It can be noticed that in the transitory seasons of the year, when a change takes place of the direction of influence exerted by the magnitude of cloudiness on air temperature - from the negative one in the warmer part of the year (March-November) to the positive one in the winter months - the correlation is close to zero. This dependence is also insignificant in January, when air temperature depends most strongly upon circulation (maximum influence of the western component of the geostrophic wind over the central part of Europe on air temperature in Poland, Kożuchowski \& Żmudzka 2002).

The tendencies of changes in precipitation and temperature correspond to the tendencies of changes in the magnitude of cloudiness over Poland, differentiated over the year. Thus, for instance, in May, when a significant negative trend in the magnitude of cloudiness has been noted, a significant increase of air temperature was registered, and a decrease of precipitation (Table 2). In these months, in which an increasing tendency was observed of the magnitude of cloudiness, that is - in June and in September, a negative temperature trend was observed, and a positive one of precipitation (Kożuchowski \& Żmudzka 2002; Żmudzka 2002, 2004, 2006). On the other hand, in March, when the influence of the magnitude of cloudiness is the weakest, and statistically insignificant, despite the positive tendency of changes in cloudiness, air temperature significantly increased. The winter and spring warming was mainly the effect of the increased intensity of the 


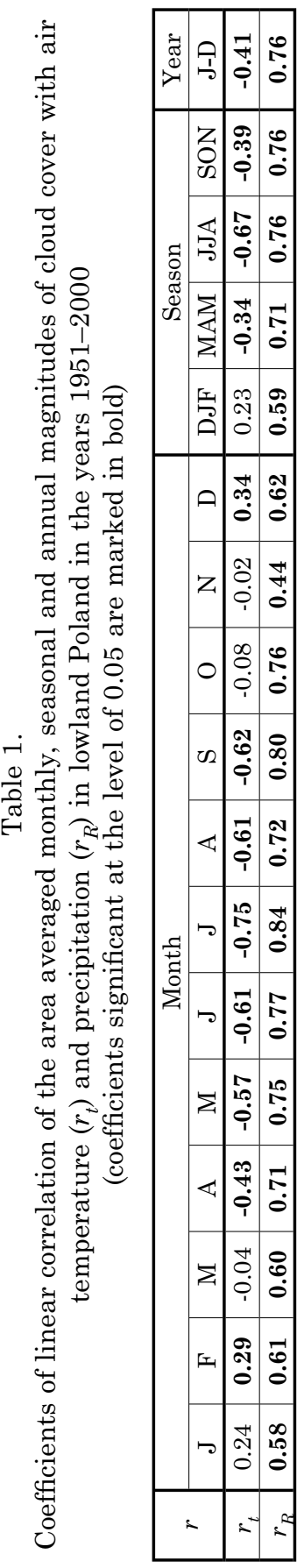

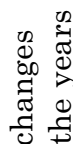

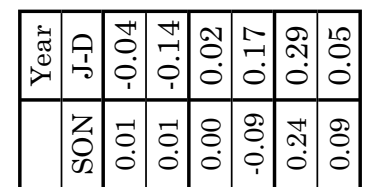

.尹 .尹

రृత్ర

2

串

㟧

잉

.

密

సี ⿷匚⿱

ट्वृ ट्व

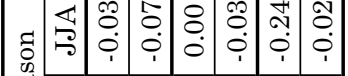

थ

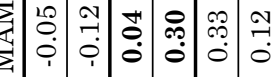

4

私苟 0

䒕部

( द)

50

엉

质

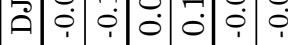

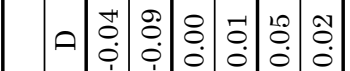

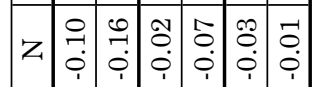

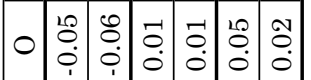

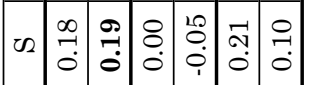

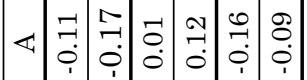

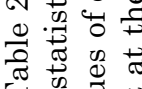

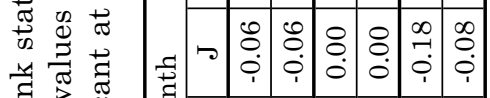

สี

䨔

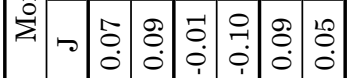

$\sigma$ व

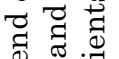

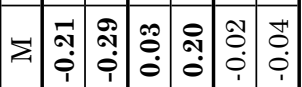

光

శี

离

क

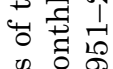

옴

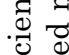

进

ठ

శ్

总焉

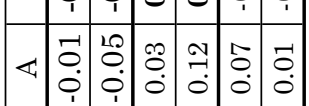

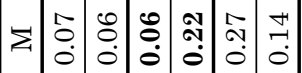

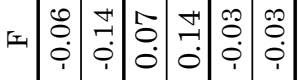

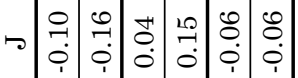

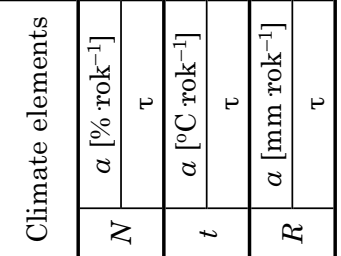


western component of atmospheric circulation within the moderate latitudes of the northern hemisphere (Kożuchowski \& Żmudzka 2002; Degirmendžić et al. 2004).

Existence of a strong association between, on the one hand, the investigated elements of climate and, on the other, cloudiness is also indicated by the appearance of definite analogies in the course of the curves, representing accumulation of the deviations from the respective 50-year average values for 1951-2000 (Fig. 1).

\section{TEMPERATURE}
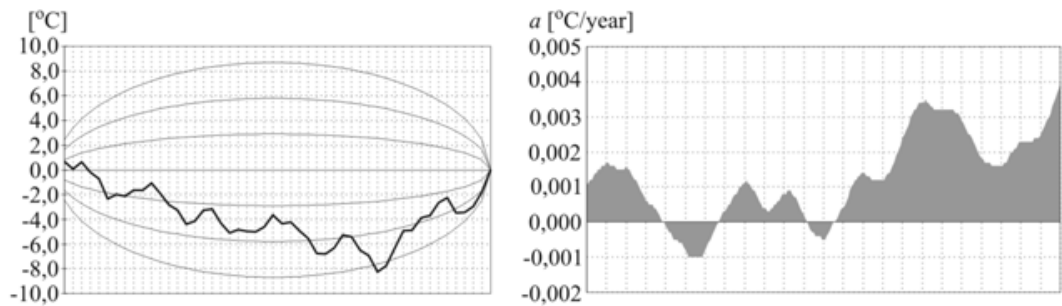

PRECIPITATION
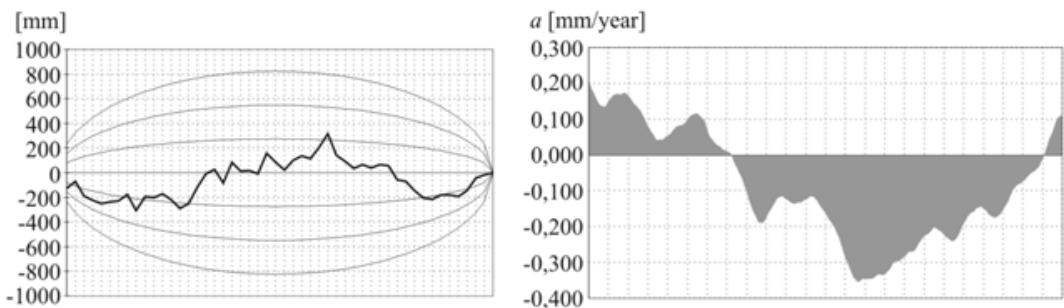

\section{CLOUDINESS}
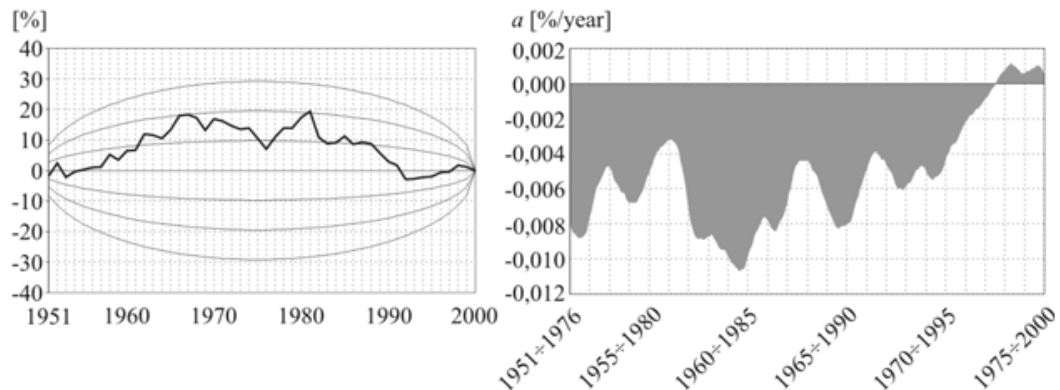

Fig. 1. Cumulative deviations of annual mean values of temperature, precipitation sums and cloudiness from the 50-years means 1951-2000 in lowland Poland (the ranges of 1,2 and 3 standard deviations are marked) and linear trend coefficients of changes $a$ in moving 25-years (Żmudzka 2004, changed) 
In the course of the annual averages of the magnitude of cloudiness three instances can be distinguished of the occurrence of a change in the trend sign (Żmudzka 2007). These three time instants are: the beginning of the 1970s and of the 1990s, and the year 1982. The latter period corresponds to a major change: in the first part of the long-term period considered the positive deviations dominated, while in the second part - the negative ones. Irrespective of certain specific features, the changes in the intensity of precipitation display synchronous variation with the changes in the magnitude of cloudiness. There is also a clear similarity of the curves, representing the cumulative deviations from the average for cloudiness and air temperature. Given the negative influence of cloudiness on this element of climate, the period of a drop in air temperature coincides with the positive tendency in the changes of the magnitude of cloudiness. The instant of the appearance of the main change in the sign of tendency in the magnitude of cloudiness precedes a bit the year, in which the change of the sign of temperature deviations took place (1988), even though certain symptoms of warming have been visible already since the year 1982 .

As we consider the long-term variability of the annual average of the magnitude of cloudiness and of other elements of climate in Poland, we can also notice a coincidence of the essential frequency of oscillations, which is constituted by the 3.6-year cycle (Fig. 2). This periodicity has been observed, in particular, in the 120-year series of cloudiness from Cracow (1861-1980; Morawska-Horawska 1985), and in the 50-year time series of cloudiness over Poland (1951-2000; Żmudzka 2007), as well as in the course of the annual average of precipitation from the years 1881-1980 (Kożuchowski 1985) and the annual air temperature values from the years 1951-1991 (Żmudzka 1999). Besides, there are several other bands of frequencies (periodicities) changes, identified in the course of the magnitude of cloudiness, that are present also in the chronological series of these elements of climate. Their contributions to the respective variability of the series are, however, different.

A comparison of the nephological calendar with the thermal and precipitation calendars confirms also a significant influence of the magnitude of cloudiness on these two elements of climate (Fig. 3). The anomalously cloudy years (1952, 1958, 1962, 1966 and 1977) are at the same time characterised by the precipitation above the norm. The anomalously clear years (1953, 1969, 1976, 1982 and 1992) belong among the very dry ones. The thermal conditions in the years with 
A)

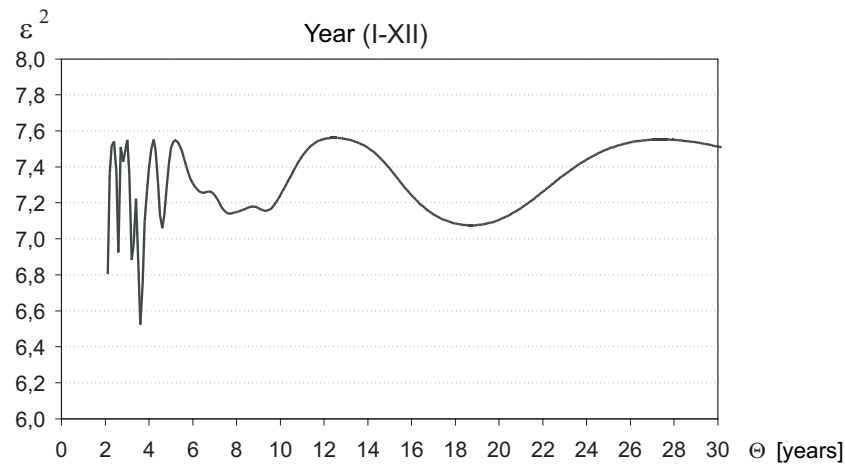

B)

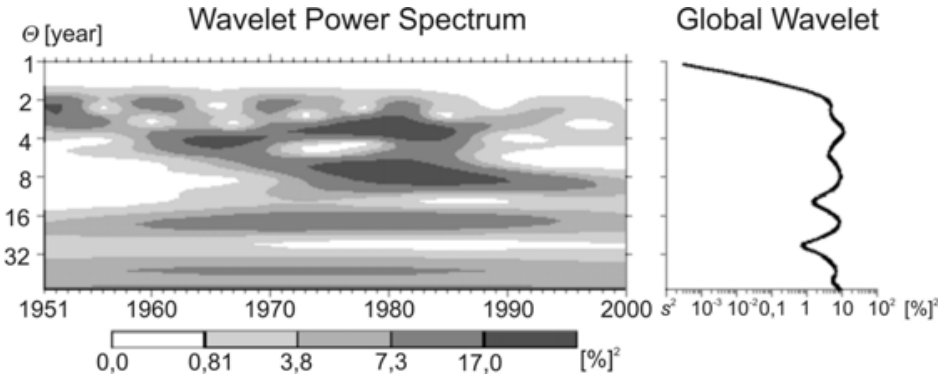

Fig. 2. Spectra (A) and wavelet analysis (B) of the annual average of cloudiness over lowland Poland (1951-2000)

anomalous magnitude of cloudiness depend upon the seasonal structure of the magnitude of cloudiness. This results from the changes during the year of the nature of influence exerted by cloudiness on air temperature. The anomalously clear years may be both very cold and very warm. The former are usually the years with exceptionally low cloudiness during the cool part of the year. In the half-century considered these were the years 1969 and 1976. During the clear year 1969 the particularly low cloudiness occurred in autumn and winter. In 1976 extremely clear was winter, even though summer was also among the anomalously clear ones. On the other hand, these of the anomalously clear years were warm, during which exceptionally low cloudiness occurred in the warm part of the year. An exceptionally strong negative anomaly of cloudiness took place in 1982, when spring, summer and autumn were extremely clear. Winter was also among the clear ones. During that year, as well, the lowest area average of 

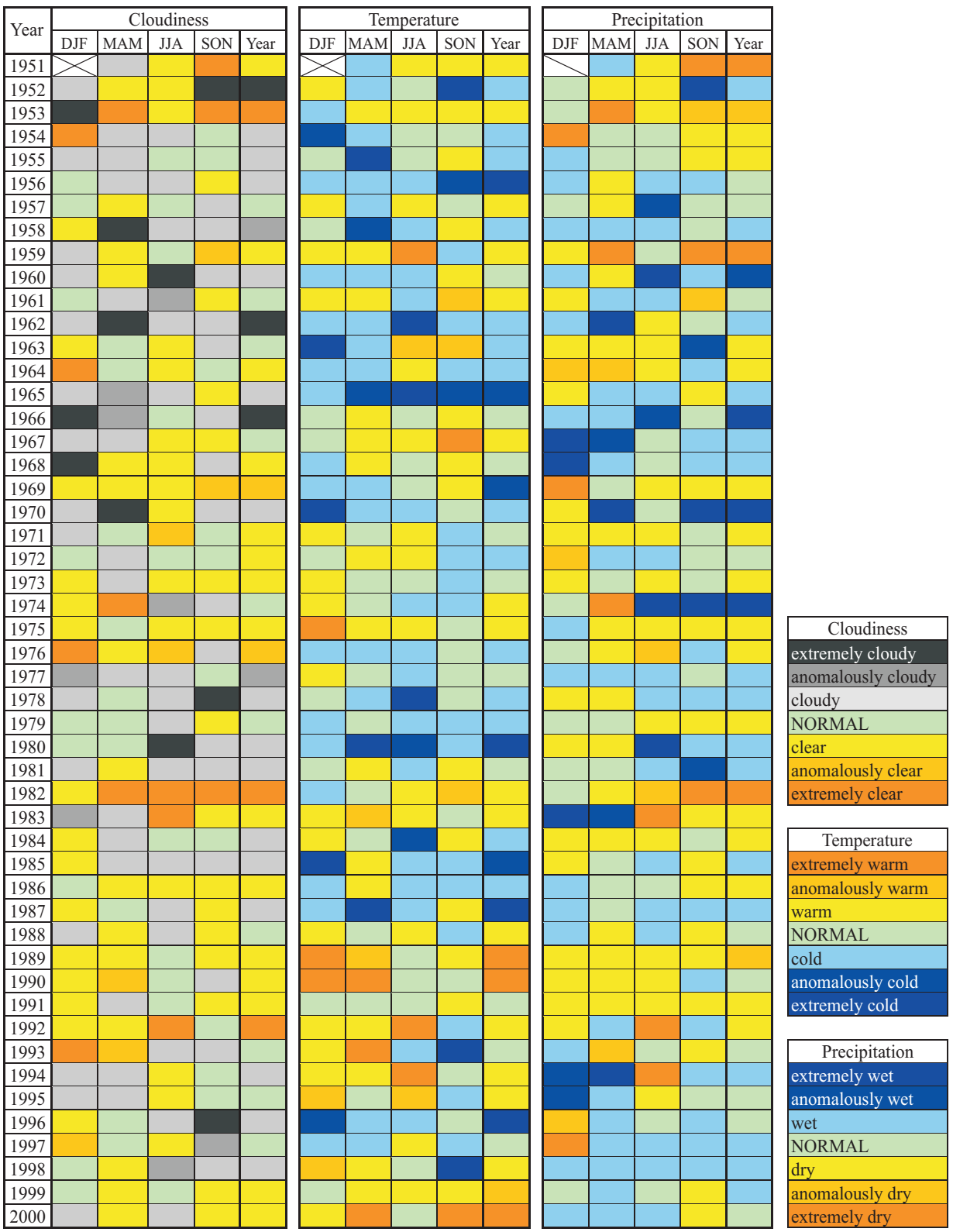

Fig. 3. Nephological, thermal and precipitation calendar of the second half of the $20^{\text {th }}$ century - seasons and year 
precipitation in the period 1951-2000 was recorded (extremely dry autumn and very dry spring and summer), see Żmudzka (2002). At the same time, this was a warm year, first of all due to the very warm autumn and warm summer.

A distinct influence of cloudiness on other elements of climate is also expressed through certain specific features of their annual course. In the period of lower cloudiness, which lasts between the second decade of April and the second decade of October, its slight increase between the third decade of May and the second one of July can be observed (Fig. 4). During the same period a weakening of the increase of temperature is observed, accompanied by an increase in precipitation in Central Europe (Schüepp \& Schirmer 1977). A decrease in sunshine in the middle of June is also the most characteristic anomaly in the annual course of this element of climate in Poland (Degirmendžić 2004). This breakdown of weather at the beginning of summer is connected with the intensification of the western advection (NW-W).
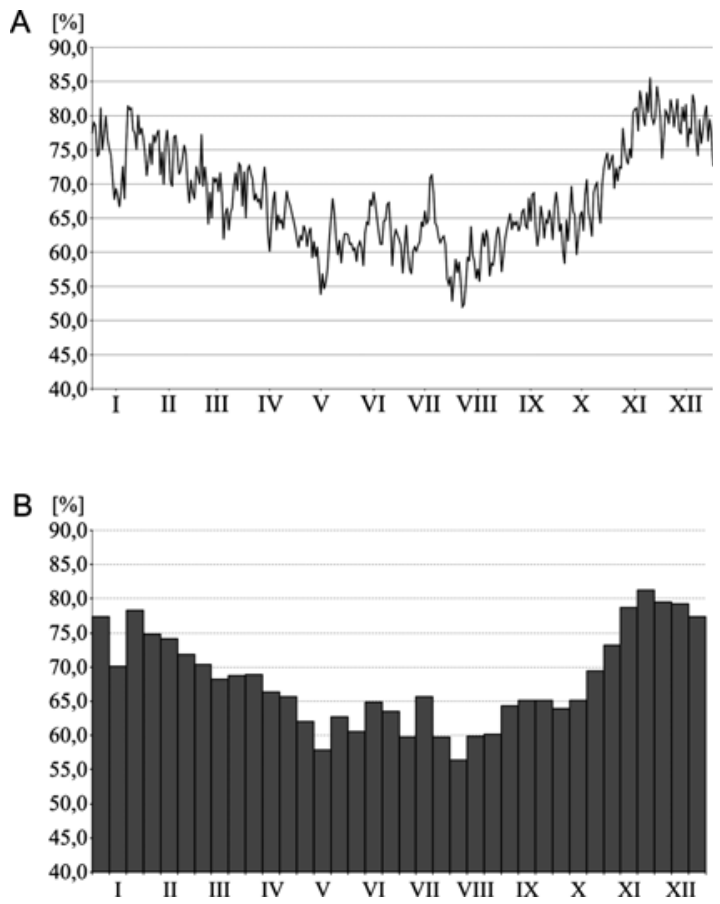

Fig. 4. The daily (A) and ten-day (B) averages of cloudiness over lowland Poland (1966-2000) 
As we compare the 10-year averages of the particular elements of climate, we can also notice that the secondary annual maximum of the magnitude of cloudiness in June (64\%) and the very low cloudiness in July and August (respectively, 57\% and 53\%) during the decade of 1981-1990 (the lowest among the average 10-year cloudiness values) corresponds with the shift of the annual maximum of precipitation in that decade from July $(70 \mathrm{~mm})$ to June $(75 \mathrm{~mm})$, see Żmudzka (2002), and also with the registering of the lowest, in the half-century considered, 10-year average temperature in June $\left(15.6^{\circ} \mathrm{C}\right)$, and the highest one in May $\left(13.6^{\circ} \mathrm{C}\right)$.

An important part of variance of the values taken by the elements of climate can be explained by the direct action of the atmospheric circulation. And so, for instance, the components of the geostrophic wind over Central Europe and the atmospheric pressure over central Poland explain between 15\% (in August) and 77\% (in January) of the variability of average air temperature values in Poland, between $10 \%$ (in August) and $46 \%$ (in July) of the variability of precipitation sums, and between $28 \%$ (in April) and $71 \%$ (in July) of the variance of the magnitude of cloudiness over Poland (see Table 3, Kożuchowski \& Żmudzka 2002; Degirmendžić et al. 2004; Żmudzka 2007).

Replacing atmospheric pressure by the magnitude of cloudiness over Poland in the respective equations significantly increases the proportion of the explained variance of the elements of climate considered, especially precipitation. In the case of air temperature this proportion equals between 34\% in October and 84\% in January, and in the case of precipitation - between $37 \%$ in November and $80 \%$ in July (Table 4).

In the shaping of the air temperature an especially important role is played by the atmospheric circulation, between November and March - mainly the western component of the geostrophic wind, in the remaining parts of the year - the northern component. The western component of the wind brings about during the entire year, except for the summer months, an increase in air temperature, while the northern component - its decrease. During the warmest months of the year (except for July) the role of cloudiness is similar to the role of the western component of the geostrophic wind. Between October and February the increase of the magnitude of cloudiness brings about an increase of the air temperature, while in the remaining parts of the year - its decrease. 


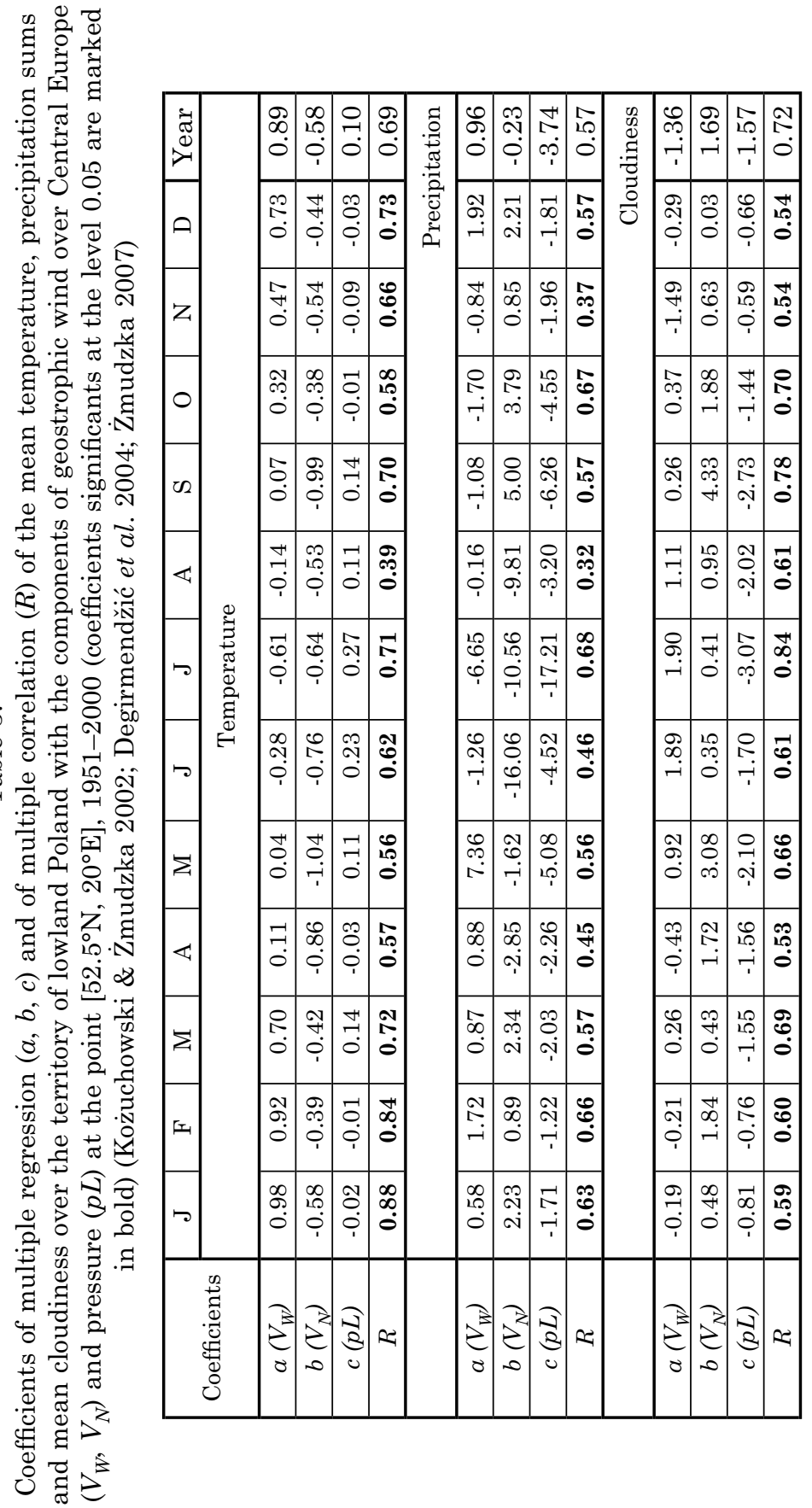




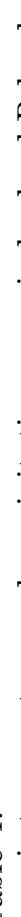

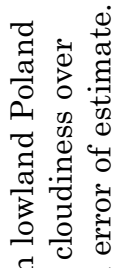

द्व 넝 웅

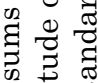

ป.

.

घ도

유요

यु

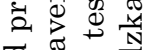

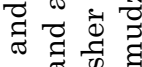

๙

矛不㟧络

बै। छี

म웡

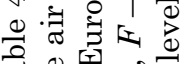

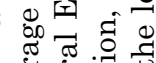

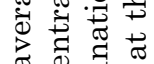
击

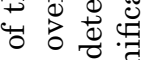

(ิ) 뜽 0.5 in

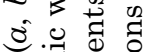

क्ञ त्र

雪苟过

ธूँ

땅 है

눈 눙

.

द्व ปี

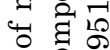

का : -1

产这

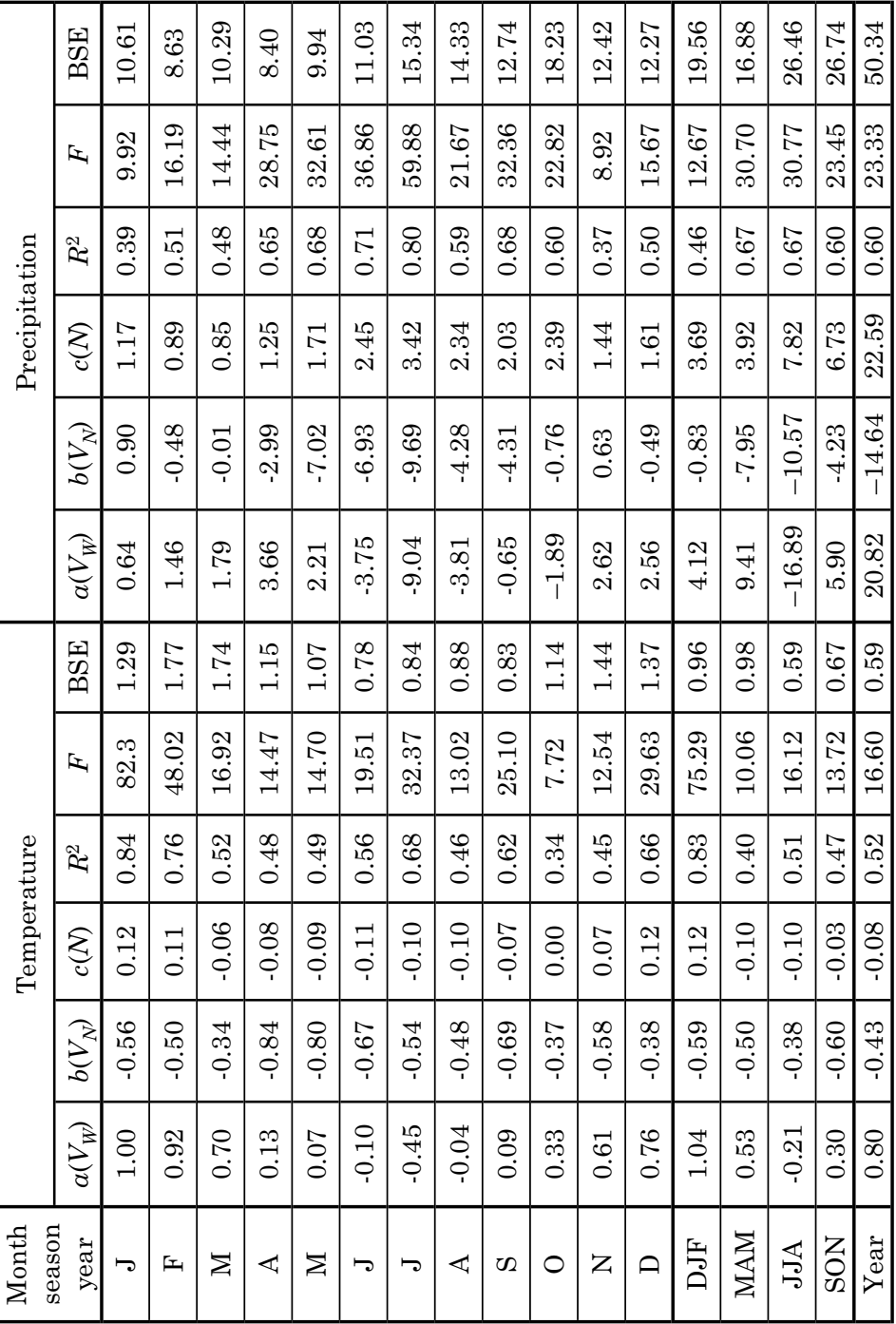

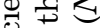

跑䨠 
Replacing in the equations linking the amount of precipitation with atmospheric circulation the atmospheric pressure by the magnitude of cloudiness over Poland does not only lead to better statistical validity of the equations, but also causes certain changes in the assessment of the influence of the components of the geostrophic wind on precipitation. During the entire year, except for January and November, precipitation over Poland decreases with the intensity of the northern circulation. The meridional exchange of the air masses is of special importance in the shaping of the precipitation totals between May and September. In January and October the most important role is played by cloudiness, while in the remaining part of the year - by the western component of the geostrophic wind. In terms of seasons of the year the magnitude of cloudiness has dominating significance in the shaping of the precipitation sums in autumn (and on the average in the year). During the entire year an increase in the magnitude of cloudiness entails an increase in precipitation. The increase of intensity of the western transfer, on the other hand, is conducive to the increase of the precipitation sums over Poland between November and May.

\section{CONCLUSIONS}

An initial assessment of interrelations between the selected elements of climate and cloudiness over Poland documents a significant climate-forming role of the magnitude of cloudiness.

The dependence of air temperature and precipitation upon cloudiness is demonstrated by the existence of analogies in their annual and long-term dynamics. The magnitude of cloudiness over Poland explains up to $70 \%$ of variability of air temperature and precipitation. The strongest relations exist in the warmer half of the year, which can be explained by the modifying influence of cloudiness on the course of processes, decisive for the thermal and precipitation processes in this part of the year.

Cloudiness, being an element of climate which is shaped mainly by the macro-scale circulation processes, explains along with the atmospheric circulation up to $85 \%$ of variability of temperature and precipitation on the territory of Poland.

An increase or decrease of the magnitude of cloudiness does not get reflected directly, of course, in the changes of values of other elements 
of climate. This influence is modified, for instance, by the structure of the cloud types. Such a role of cloudiness results, as well, from the fact that cloudiness is but one of many factors, having significant influence on the formation of climate.

\section{REFERENCES}

Barry R. G., Crane R. G., Schwiger A., Newell J., 1987, Arctic cloudiness in spring from satellite imagery. J. Climatol., 7, 423-451.

Boryczka J., 1998, Zmiany klimatu Ziemi [Changes of the Earth's climate; in Polish]. Wyd. Akademickie DIALOG, Warszawa.

Cess R. D. et al., 1996, Cloud feedback in atmospheric general circulation models: an update. J. Geophys. Res., 101, D8, 12791-12794.

Degirmendžić J., 2004, Zmiany usłonecznienia w Polsce i ich uwarunkowania cyrkulacyjne [Changes of sunshine duration in Poland and their relationship to atmospheric circulation; in Polish]. [in:] K. Kożuchowski (ed.) Skala, uwarunkowania i perspektywy wspótczesnych zmian klimatycznych $w$ Polsce [Scale, conditions and perspectives of the contemporary climatic changes in Poland; in Polish], Zakład Dynamiki Środowiska i Bioklimatologii UŁ, Wydawnictwo „Biblioteka”, Łódź, 9-23.

Degirmendžić J., Kożuchowski K., Żmudzka E., 2004, Changes of air temperature and precipitation in Poland in the period 1951-2000 and their relationship to atmospheric circulation. Int. J. Climatol., 24, 3, 291-310.

Fortuniak K., Kożuchowski K., Żmudzka E., 2001, Trendy i okresowość zmian temperatury powietrza w Polsce w drugiej połowie XX wieku [Trends and periodicity of changes in air temperature in Poland in the second half of $20^{\text {th }}$ century; in Polish]. Prz. Geof., 46, 4, 283-303.

Kożuchowski K., 1985, Zmienność opadów atmosferycznych w Polsce w stuleciu 1881-1980 [Variation in precipitation in the years 1881-1980 in Poland; in Polish]. Acta Geogr. Lodz., 48.

Kożuchowski K., Żmudzka E., 2002, Cyrkulacja atmosferyczna i jej wpływ na zmienność temperatury powietrza w Polsce [Atmospheric circulation and its influence on air temperature variation in Poland; in Polish]. Prz. Geogr., 74, 4, 591-604.

Morawska-Horawska M., 1985, Cloudiness and sunshine in Cracow, 1861-1980, and its contemporary tendencies. J. Climatol., 5, 633-642.

Norris J. R., 2004, Implications of cloudiness changes since 1952. Bull. Amer. Meteorol. Soc., 85, 3, 346-347.

Schüepp M., Schirmer H., 1977, Climates of Central Europe. [in:] C. C. Wallén (ed.) Climates of Central and Southern Europe, t. 6. World Survey of Climatology, Elsevier Scientific Publishing Company, Amsterdam-Oxford-New York, 3-73.

Svensmark H., Friis-Christensen E., 1997, Variations of cosmic ray flux and global cloud coverage. A Missing link in solar-climate relationships. J. Atm. and Solar-Terrestrial Physics, 59(11), 1225-1232. 
Torrence Ch., Compo G.P., 1998, A practical guide to wavelet analysis. Bull. Amer. Meteorol. Soc., 79, 61-78.

Wetherald R. T., Manabe S., 1980, Cloud cover and climate sensitivity. J. Atm. Sci., 37, 1485-1510.

Żmudzka E., 1999, Krótkookresowa zmienność temperatury powietrza w Polsce [Short-term variability of the air temperature in Poland; in Polish]. Prz. Geof., 44, 3, 115-130.

Żmudzka E., 2002, O zmienności opadów atmosferycznych na obszarze Polski nizinnej $\mathrm{w}$ drugiej połowie $\mathrm{XX}$ wieku [On the atmospheric precipitation variability in lowland Poland in the second half of the $20^{\text {th }}$ century; in Polish]. Wiad. IMGW, $25,4,23-38$.

Żmudzka E., 2004, Tendencje zmian a zróżnicowanie przestrzenne elementów klimatu w Polsce w drugiej połowie XX wieku [Change tendencies and spatial different of climate elements in Poland in second half of the $20^{\text {th }}$; in Polish]. [in:] Z. Michalczyk (ed.) Badania geograficzne w poznawaniu środowiska [Geographical research in study of environment; in Polish], Wydawnictwo UMCS, Lublin, 452-458.

Żmudzka E., 2006, Variability of climate in Central Europe the example of Poland 1951-2000, Acta Geographica Universitatis Comenianae, 49, 213-226.

Żmudzka E., 2007, Zmienność zachmurzenia nad Polska i jej uwarunkowania cyrkulacyjne (1951-2000) [Variability of cloudiness over Poland and its circulation-related conditioning; in Polish], Wydawnictwa Uniwersytetu Warszawskiego, Warszawa.

English translation: Jan Owsiński 